\title{
Binding Modes of a trans-Vinylbipyridinium Surfactant Bearing a Hexadecyl Chain to Cucurbit[n]uril $(n=6-8)$ in Aqueous Solution
}

\author{
Young Jin Jeon, ${ }^{\text {a }}$ Young Ho Ko, and Kimoon Kim ${ }^{*}$ \\ Department of Chemisty, National Creative Research Initiative Center for Smart Sipramolecules, \\ Pohang University of Science and Technology, Pohang 790-784, Korea. "E-mail: kkim@ipostechac.kr \\ Received August 11, 2008
}

Key Words : Cucurbituril, Polar lipids, Guest inclusion, NMR study, Alkyl folding

Alkyl chains of naturally occurring fatty acids usually adopt the strain-free extended conformation in solution or gas phase. ' However, the conformations of alkyl chains are highly environment-dependent. Sometimes they adopt unusual, seemingly high-energy conformations. ${ }^{2.3}$ For example, alkyl chains confined in synthetic hosts adopt helical conformations. Another example is U-shaped conformations. ${ }^{2}$ Fatty acid binding proteins (FABPs) offer special environments for fatty acids such as palmitic acid and oleic acid to adopt a "L-shaped" conformation." The back-folding phenomenon of aliphatic chains found in Nature was scarcely observed in synthetic systems until recently. An alkyl chain bound to the cavity of $/$-cyclodextrin $(\gamma-C D)$ was suggested to adopt a $U$-shaped conformation based on fluorescence life-time measurements, which has never been confirmed, however. ${ }^{+}$Recently, we reported an unequivocal example of the back-folding of aliphatic chains bound to a synthetic host. ${ }^{5}$ The alkyl chains of alkyltrimethylammonium ions bound to a hydrophobic cavity of cucurbit[8]uril (CB[8]), a member of host family cucurbit $[n]$ uril (CB $[n], n=5-10),{ }^{6.7}$ adopt a $\mathrm{U}$-shaped conformation, which has been unequivocally characterized by various methods. ${ }^{5}$ However, the same alkyl chains of alkyltrimethylammonium ions were found to have an extended conformation when bound to $\mathrm{CB}[6]$ or $\mathrm{CB}[7] .^{5}$ Extending this work, we investigated the host-guest complex formation of $\mathrm{CB}[n]$ with other types of amphiphilic molecules containing a long alkyl chain. ${ }^{8}$ Herein, we report different binding modes of an amphiphilic molecule comprising a vinylbipyridinium unit as a polar head and a hexadecyl chain as a hydrophobic tail to $\mathrm{CB}[n](n=6,7$, and 8 ) in aqueous solution, and discuss the different conformations adopted by the alkyl chain.

\section{Experimental Section}

General Methods. All the chemicals were used as received. $\mathrm{CB}[n](n=6,7$, and 8 ) were synthesized according to the literature method. ${ }^{7:} \mathrm{C}_{1} \mathrm{VPyC}_{16}{ }^{2-}$ was synthesized using the literature method $^{8}$ with some modification. All the XMR spectra were recorded on a Bruker DRX500 NMR spectrometer operating at the proton Larmor frequency of

"Present address: Department of Applied Chemistry, College of Natural Sciences, Konkuk Lniversity, Chungju 380-701, Korea
500.23 MHz. ESI mass spectra were obtained from Korea Basic Science Institute in Daejon.

$\mathrm{C}_{1} \mathrm{VPyC}_{16}{ }^{2+} \mathrm{Br}^{-} \mathrm{I}^{-}$: ${ }^{1} \mathrm{H}$ NMR (D2O, $\left.500 \mathrm{MHz}, 25{ }^{\circ} \mathrm{C}\right) \delta=$ $0.86(\mathrm{t}, J=6.5 \mathrm{~Hz}, 3 \mathrm{H}), 1.24(\mathrm{br}, 22 \mathrm{H}), 1.35(\mathrm{~s}, 4 \mathrm{H}), 2.06$ $(\mathrm{m}, 2 \mathrm{H}), 4.40(\mathrm{~s}, 3 \mathrm{H}), 4.63(\mathrm{~m}, 2 \mathrm{H}), 7.91(\mathrm{~s}, 2 \mathrm{H}), 8.26(\mathrm{t}, J=$ $6.0 \mathrm{~Hz}, 4 \mathrm{H}), 8.80(\mathrm{~d}, J=6.0 \mathrm{~Hz}, 2 \mathrm{H}), 8.88(\mathrm{~d}, J=6.5 \mathrm{~Hz}$, $2 \mathrm{H})$. ESI mass: $m / z=211.18\left[\mathrm{M}-\mathrm{Br}^{-}-\mathrm{I}^{-}\right]^{2+}$

$\mathrm{C}_{1} \mathrm{VPyC}_{16}{ }^{2+} \mathrm{Br}^{-} \mathrm{I}^{-} \cdot \mathrm{CB}[6](1): \mathrm{CB}[6](1.6 \mathrm{mg}, 1.6 \mu \mathrm{mol})$ was added to $\mathrm{C}_{1} \mathrm{VPyC}_{16}{ }^{2-} \mathrm{Br}^{-} \mathbf{I}^{-}(1.0 \mathrm{mg}, 1.6 \mu \mathrm{mol})$ in $\mathrm{D}_{2} \mathrm{O}$ (1 $\mathrm{mL}$ ) and sonicated for ca. $10 \mathrm{~min}$ to ensure complete dissolution. ${ }^{l} \mathrm{H} \times \mathrm{MR}\left(\mathrm{D}_{2} \mathrm{O}, 500 \mathrm{MHz}, 25^{\circ} \mathrm{C}\right) \delta=0.88(\mathrm{t}, J=$ $6.5 \mathrm{~Hz}, 3 \mathrm{H}), 1.28(\mathrm{~m}, 22 \mathrm{H}), 1.42(\mathrm{~m}, 4 \mathrm{H}), 2.11(\mathrm{~m}, 2 \mathrm{H}), 4.30$ $(\mathrm{s}, 12 \mathrm{H}), 4.33(\mathrm{~m}, 3 \mathrm{H}), 4.66(\mathrm{t}, J=7.0 \mathrm{~Hz}, 2 \mathrm{H}), 5.54(\mathrm{~s}$, $12 \mathrm{H}), 5.74(\mathrm{~d}, J=15.5 \mathrm{~Hz}, 12 \mathrm{H}), 7.06(\mathrm{~s}, 2 \mathrm{H}), 7.10(\mathrm{~s}, 1 \mathrm{H})$, $7.62(\mathrm{~d}, J=16.5 \mathrm{~Hz}, 1 \mathrm{H}), 8.29(\mathrm{~d}, J=6.0 \mathrm{~Hz}, 2 \mathrm{H}), 8.83(\mathrm{~d}, J$ $=6.5 \mathrm{~Hz}, 2 \mathrm{H}), 8.88(\mathrm{~d}, J=6.5 \mathrm{~Hz}, 2 \mathrm{H})$. ESI mass: $m / z=$

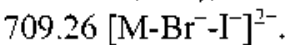

$\mathrm{C}_{1} \mathrm{VPyC}_{16}{ }^{2+} \mathrm{Br}^{-} \mathrm{I}^{-} \cdot \mathrm{CB}[7](2): \mathrm{CB}[7](3.3 \mathrm{mg}, 1.6 \mu \mathrm{mol})$ was added to $\mathbf{C}_{1} \mathbf{V P y C}_{16^{2-}}{ }^{{ }^{-}} \mathrm{Br}^{-} \mathbf{I}^{-}(1.0 \mathrm{mg}, 1.6 \mu \mathrm{mol})$ in $\mathrm{D}_{2} \mathrm{O}$ $(1 \mathrm{~mL}$ ) and sonicated for ca. $10 \mathrm{~min}$ to ensure complete dissolution. ' $\mathrm{H}$ NMR ( $\mathrm{D}_{2} \mathrm{O}, 500 \mathrm{MHz}, 25^{\circ} \mathrm{C}$ ) $\delta=0.88$ (br, $3 \mathrm{H}), 1.29$ (br, 22H) 1.48 (br, $4 \mathrm{H}), 2.11$ (br, $2 \mathrm{H}), 4.26$ (d, $J=$ $15.5 \mathrm{~Hz}, 14 \mathrm{H}), 4.44$ (br, $3 \mathrm{H}), 4.49(\mathrm{br}, 2 \mathrm{H}), 5.55(\mathrm{~s}, 14 \mathrm{H})$, $5.75(\mathrm{~d}, J=15.5 \mathrm{~Hz}, 14 \mathrm{H}), 6.96-7.07(\mathrm{~m}, 2 \mathrm{H}), 7.59(\mathrm{br}, 2 \mathrm{H})$, 7.91 (s, 2H), 8.73 (br, 2H), 8.67 (br, $2 \mathrm{H})$. ESI mass: $m / z=$ $792.26\left[\mathrm{M}-\mathrm{Br}^{-}-\mathrm{I}^{-}\right]^{2-}$.

$\mathrm{C}_{1} \mathrm{VPyC}_{16}{ }^{2+} \mathrm{Br}^{-} \mathrm{I}^{-} \cdot \mathrm{CB}[8](3): \mathrm{CB}[8](2.8 \mathrm{mg}, 1.6 \mu \mathrm{mol})$ was added to $\mathrm{C}_{1}$ VPyC $_{16}{ }^{2-} \mathbf{B r}^{-} \mathbf{I}^{-}(1.0 \mathrm{mg}, 1.6 \mu \mathrm{mol})$ in $\mathrm{D}_{2} \mathrm{O}$ $(1 \mathrm{~mL}$ ) and sonicated for $\mathrm{ca} .10 \mathrm{~min}$ to ensure complete dissolution. ' $\mathrm{H}$ NMR ( $\left.\mathrm{D}_{2} \mathrm{O}, 500 \mathrm{MHz}, 25^{\circ} \mathrm{C}\right) \delta=0.21$ (br, $2 \mathrm{H}), 0.29$ (br, $2 \mathrm{H}), 0.40$ (br, $4 \mathrm{H}), 0.53$ (br, $2 \mathrm{H}), 0.57$ (br, $4 \mathrm{H})$, 0.64 (br, $2 \mathrm{H}), 0.81$ (t, $J=7.5 \mathrm{~Hz}, 3 \mathrm{H}), 0.88$ (br, 2H), 1.02 (br, $2 \mathrm{H}), 1.13$ (br, 2H), 1.25 (br, 2H), 2.02 (br, 2H), 4.23 (d, $J=$ $15.0 \mathrm{~Hz}, 16 \mathrm{H}), 4.47(\mathrm{~s}, 3 \mathrm{H}), 4.61(\mathrm{~s}, 2 \mathrm{H}), 5.53(\mathrm{~s}, 16 \mathrm{H}), 5.81$ $(\mathrm{m}, 16 \mathrm{H}), 7.21(\mathrm{~m}, 2 \mathrm{H}), 7.49(\mathrm{br}, 2 \mathrm{H}), 8.39$ (br, 2H), 8.42 (br, $2 \mathrm{H}$ ), 8.84 (d, $J=5.0 \mathrm{~Hz}, 2 \mathrm{H}$ ). ESI mass: $m / z=875.30$ $\left[\mathrm{M}-\mathrm{Br}^{-}-\mathrm{I}^{-}\right]^{2-}$.

\section{Results and Discussion}

We investigated the binding phenomena of an amphiphilic molecule containing a long alkyl chain, $(E)$-1-hexadecyl-4(2-(1-methylpyridinium-4-yl) winyl)pyridinium ion $\left(\mathrm{C}_{1}\right.$ VPy$\mathrm{C}_{16}{ }^{2-}$ ), with $\mathrm{CB}[n](n=6,7$ and 8$)$ in aqueous solution by 

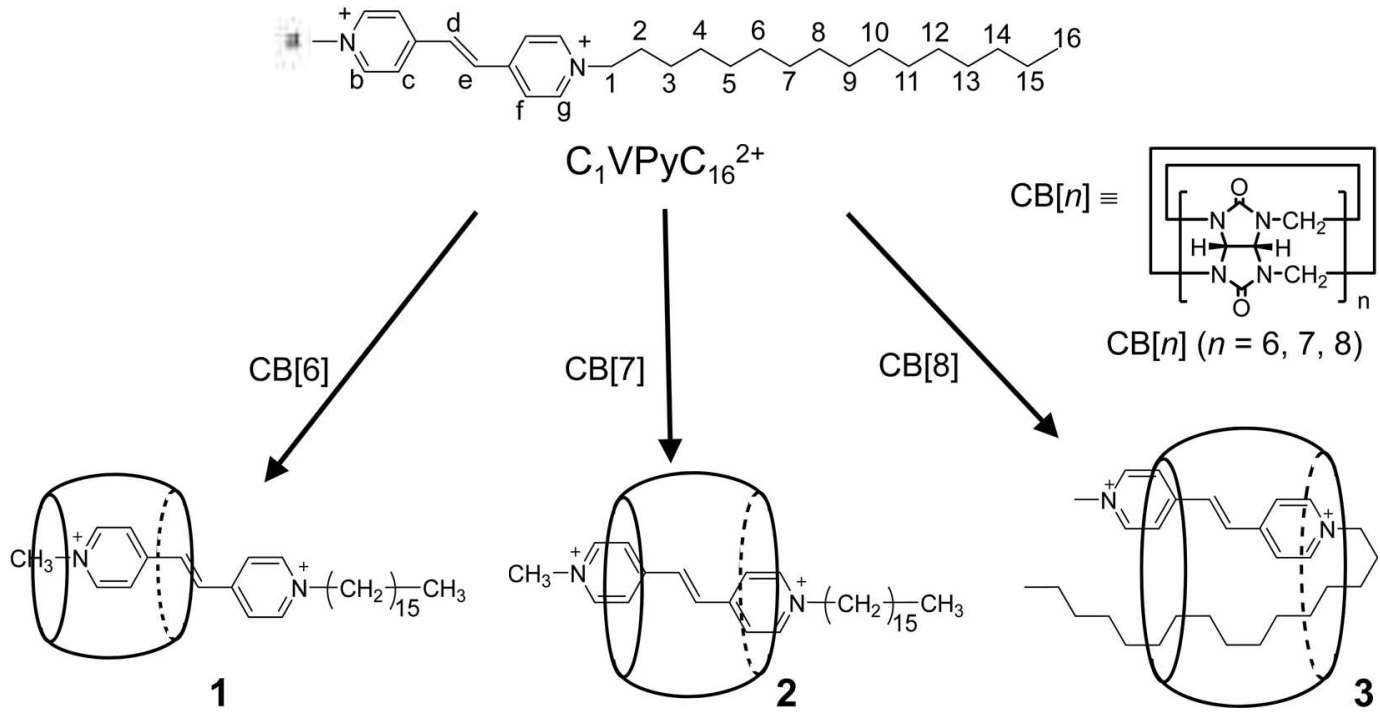

$\mathrm{CB}[n](n=6,7,8)$

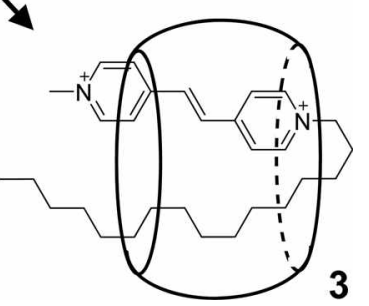

Scheme 1. Formations of 1:1 Host-guest complexes $(1,2$ and 3$)$ formed between $\mathbf{C}_{3} V P_{y} C_{16}{ }^{3+}$ and $C B[6]$. $C B[7]$ and $C B[8]$. respectively.

NMR spectroscopy. $\mathrm{CB}[6], \mathrm{CB}[7]$ and $\mathrm{CB}[8]$ form $1: 1$ hostguest complexes (1.2 and 3 , respectively) with $\mathbf{C}_{1} \mathbf{V P y C} \mathbf{C}_{16}{ }^{2+}$ in aqueous solution, which was also confirmed by ESI mass spectrometry.

First, upon adding $\mathrm{CB}[6]$ to $\mathrm{C}_{1} \mathrm{VPyC}_{16}{ }^{2-}$ in $\mathrm{D}_{2} \mathrm{O}$ solution. the $\mathrm{C}_{c}$ and $\mathrm{C}_{b}$ proton peaks in ${ }^{1} \mathrm{H}$ NMR spectra (Figure la and $1 \mathrm{~b}$ ) are upfield-shifted by 1.20 and $0.81 \mathrm{ppm}$, respectively, indicating that the terminal pyridinium part of $\mathrm{C}_{1} \mathrm{VPyC}_{16}{ }^{2+}$ ion is included in the cavity of $\mathrm{CB}[6]$ as

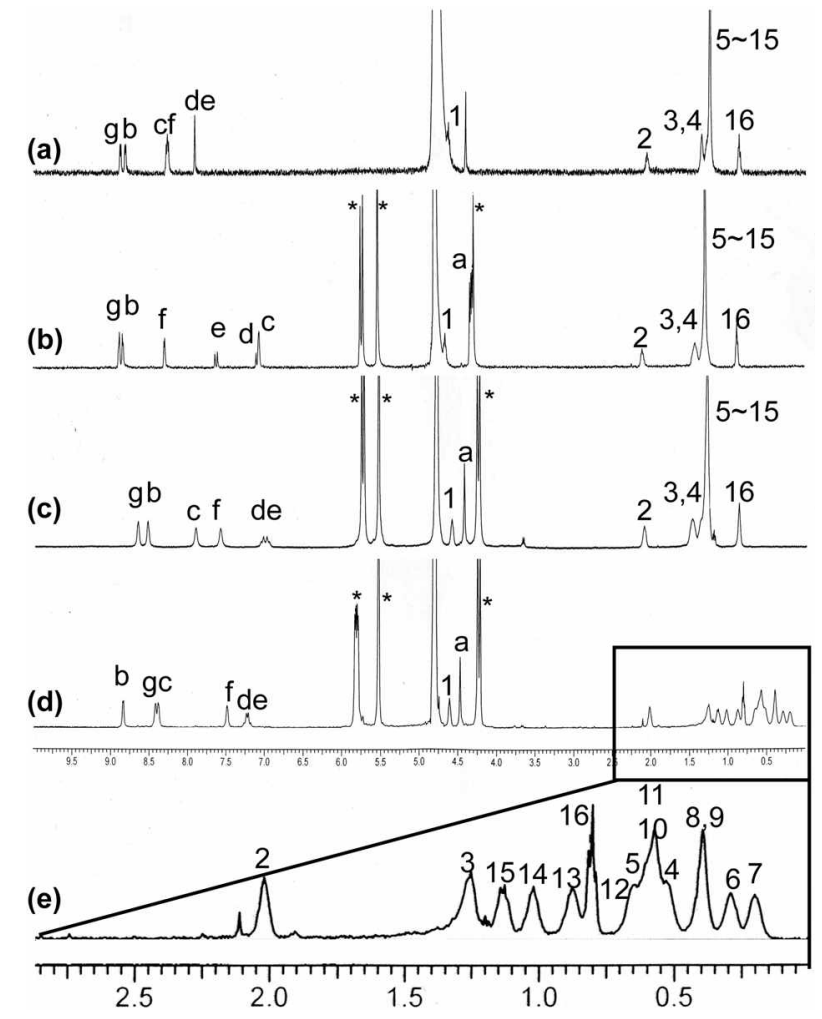

Figure 1. ${ }^{1} \mathrm{H}$ NMR spectra of $\mathbf{C}_{1} \mathrm{VPyC}_{16}{ }^{2+}$ in the (a) absence of $\mathrm{CB}[n]$, and in the presence of 1 equivalent of (b) $\mathrm{CB}[6]$ : (c) $\mathrm{CB}$ [7] and (d) $\mathrm{CB}[8]$, and (e) enlarged spectrum of (d) in $\mathrm{D}_{2} \mathrm{O}$ at $298 \mathrm{~K}$. illustrated in Scheme 1. Apparently, the small cavity size of $\mathrm{CB}[6]$ makes the host localized on terminal pyridinium part of $\mathrm{C}_{1} \mathrm{VPyC}_{16}{ }^{2+}$ in 1 . In contrast to the proton peaks of the hydrophilic head, those of the hydrophobic tail show no significant change in chemical shift, which indicates the alkyl chain is located outside of the $\mathrm{CB}[6]$ cavity adopting presumably an extended conformation. The complex formation between $\mathrm{C}_{1} \mathrm{VPyC}_{16^{2-}}$ and $\mathrm{CB}[6]$ enhances their solubility in water as evidenced by the decreased noise level in the XMR spectra when two components are mixed in $\mathrm{D}_{2} \mathrm{O}$ solution (Figure 1b). In addition, ESI mass spectrometry confirms the stability of the host-guest complex $\mathbf{1}$ in solution.

The XMR spectrum of complex 2, formed between $\mathrm{C}_{1} \mathrm{VPyC}_{16^{2-}}$ ion and $\mathrm{CB}[7]$, shows that the proton peaks corresponding to the vinylbipyridinium unit are broadened and upfield-shifted (0.3-1.0 ppm) in $\mathrm{D}_{2} \mathrm{O}$ solution compared to those of free $\mathbf{C}_{1} \mathbf{V P y C}_{16}{ }^{1+}$ (Figure lc) whereas those of the hydrophobic tail show no significant changes, indicating that $\mathrm{CB}[7]$ encircles the vinylbipyridinium unit while the hydrophobic tail remains outside the $\mathrm{CB}[7]$ cavity, adopting an extended conformation. The NMR pattern suggests that $\mathrm{CB}[7]$ slowly moves back and forth along the vinylbipyridinium unit on the NMR time scale. ESI mass spectrometry also confirms the formation of complex 2 in $\mathrm{D}_{2} \mathrm{O}$ solution.

$\mathrm{CB}[8]$, the largest member of the $\mathrm{CB}[n]$ used in this study, shows unique host-guest chemistry derived from its large cavity ${ }^{7 a, 9}$ The NMR spectra of $\mathbf{3}$ show that the proton peaks of the hydrophobic tail become complicated and are distinctly separated (Figure 1d). The proton peaks corresponding to $C_{i t}-C_{g}$ of the hydrophilic head are upfield-shifted by 0.4-0.8 ppm and others $\left(\mathrm{C}_{\mathrm{u}}-\mathrm{C}_{\mathrm{c}}\right)$ are slightly downfieldshifted, while those corresponding to $\mathrm{C}_{4}-\mathrm{C}_{12}$ of the hydrophobic hexadecyl tail are upfield-shifted by $0.6-1.1 \mathrm{ppm}$ (Table 1), which indicates that the vinylbipyridinium part close to the hexadecyl chain and $\mathrm{C}_{4}-\mathrm{C}_{12}$ of the hexadecyl chain are buried inside the cavity of $\mathrm{CB}[8]$ as illustrated in 

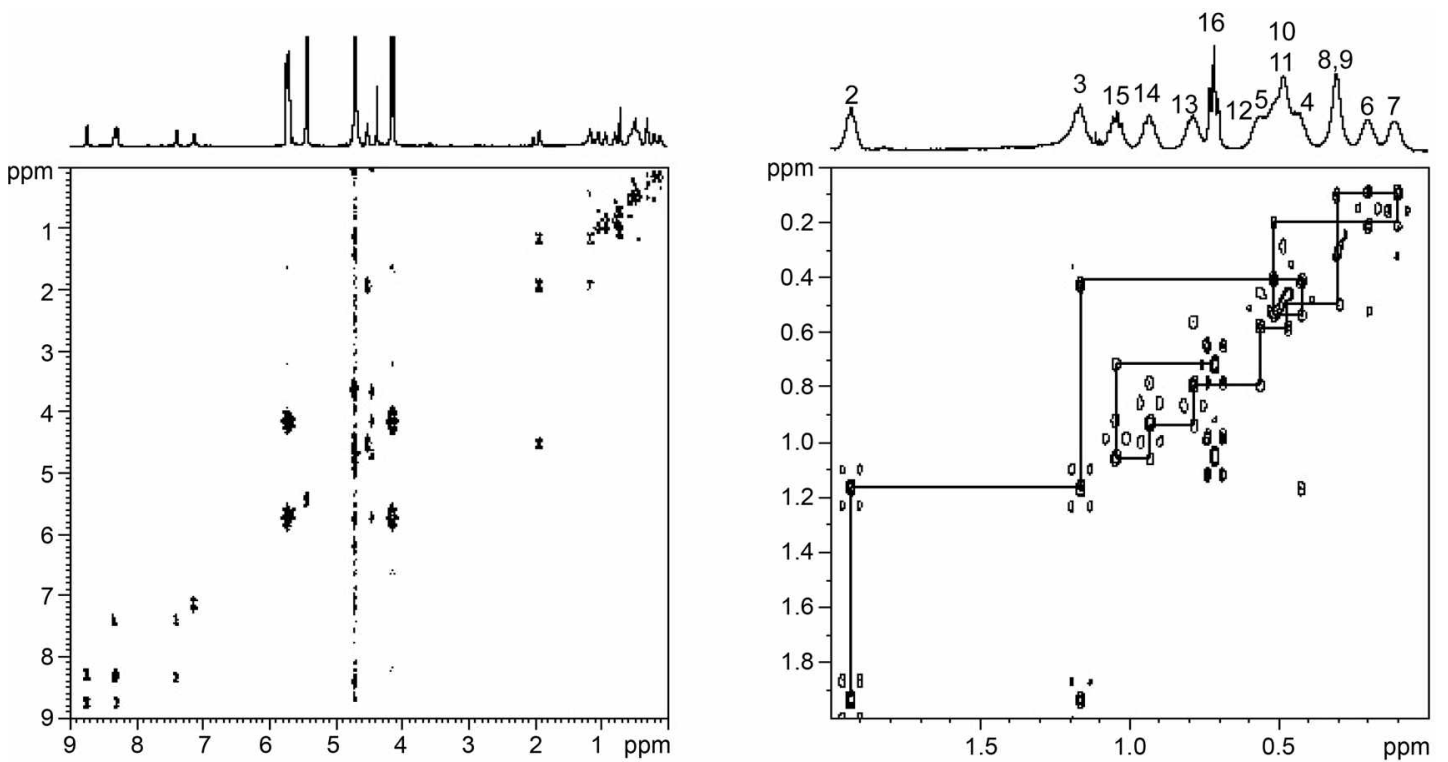

Figure 2. DQF-COSY spectra of complex 3. Full span of spectrum (left) and enlarged view of alkyl tail part (right) are shown respectively $\left(D_{2} \mathrm{O} .25^{\circ} \mathrm{C}\right)$.

Table 1. Relaxation times $\left(T_{1}\right)$ and complexation-induced chemical shifts $(4 \delta)$ for the complex 3 in $\mathrm{D}, \mathrm{O}\left(500 \mathrm{MHz}, 25^{\circ} \mathrm{C}\right)$. Assignment of numbers of carbons $\left(\mathrm{C}_{t}\right)$ are illustrated in Schene 1

\begin{tabular}{|c|c|c|c|c|c|c|c|c|c|c|c|c|}
\hline$n$ & $\mathbf{a}$ & b & c & d & e & f & g & 1 & 2 & 3 & 4 & 5 \\
\hline$T_{\mathrm{l}}$ & 1.07 & 1.44 & 1.16 & 0.93 & 0.93 & 1.11 & - & 0.45 & 0.35 & 0.41 & 0.44 & - \\
\hline 16 & -0.08 & -0.04 & -0.14 & 0.64 & 0.71 & 0.79 & 0.44 & 0.01 & 0.03 & 0.09 & 0.74 & 0.66 \\
\hline$n$ & 6 & 7 & 8 & 9 & 10 & 11 & 12 & 13 & 14 & 15 & 16 & \\
\hline$T_{\mathrm{l}}$ & 0.45 & 0.47 & 0.52 & 0.52 & 0.57 & 0.57 & 0.57 & 0.63 & 0.81 & 1.11 & 1.48 & \\
\hline$\Delta \delta$ & 1.01 & 1.09 & 0.88 & 0.85 & 0.65 & 0.67 & 0.59 & 0.36 & 0.22 & 0.11 & 0.06 & \\
\hline
\end{tabular}

Scheme 1. Interestingly, each methylene unit of the alkyl chain bound to the $\mathrm{CB}[8]$ cavity resonates at a different chemical shift value in the ${ }^{1} \mathrm{H}$ XMR spectrum (Figure le). Double-quantum filtered correlation spectroscopy (DQFCOSY) was used to assign each peak unequivocally and to establish the connectivity of each peak for the hexadecyl chain of $\mathrm{C}_{1} \mathrm{VPyC}_{16}{ }^{2-}$ inside $\mathrm{CB}[8]$ (Figure 2). All the proton peaks of the hexadecyl unit were assigned as shown in Figures 1e and 2. Based on the XMR observation we propose the structure of 3 as shown in Scheme 1, in which the vinylbipyridinium unit and a part of the hydrophobic tail of $\mathbf{C}_{1} \mathbf{V P y C}_{16}{ }^{2-}$ are located inside the hydrophobic cavity of $\mathrm{CB}[8]$ by backfolding of the alkyl chain, similar to the complexes between $\mathrm{CB}[8]$ and alkyltrimethylammonium ions. ${ }^{5}$ The much shorter spin-lattice relaxation times $\left(T_{1}\right)$ of the protons of the vinylbipyridinium part and aliphatic chains in $\mathbf{3}$ compared to those of free $\mathbf{C}_{1} \mathbf{V P y C}_{16}{ }^{2-}$, which are consistent with the structure, reflect a highly restricted motion of $\mathrm{C}_{1} \mathrm{VPyC}_{16}{ }^{2-}$ inside $\mathrm{CB}[8]$ (Table 1).

In summary, the surfactant, $\mathbf{C}_{1} \mathbf{V P y C}_{16}{ }^{2-}$, forms $1: 1 \mathrm{com}$ plexes with $\mathrm{CB}[6], \mathrm{CB}[7]$ and $\mathrm{CB}[8]$ in different binding modes depending on the cavity sizes. When it forms a complex with $\mathrm{CB}[6]$, only one side of the vinylbipyridinium unit close to the terminal methyl group is included inside the host cavity, while the aliphatic chain is stretched out of the cavity. Similarly, $\mathrm{CB}[7]$ forms a complex with the surfactant by encircling the vinylbipyridinium unit, but the larger cavity allow the host to move back and forth along the vinylbipyridinium unit. However, the complexation of the surfactant with $\mathrm{CB}[8]$ results in backfolding of the aliphatic chain inside the cavity $\mathrm{CB}[8]$. Along with our previous work, the present study demonstrates an unusual U-shaped conformation of alkyl chains bound to a synthetic host, which is closely related to that of fatty acids bound to FABPs. Thus, this finding not only contributes to the understanding of the unusual conformation of alkyl chains found in Nature, but also gives an insight into the construction of elaborate supramolecular assemblies and molecular machines based on $\mathrm{CB}[n]$-aliphatic chain interactions.

Acknowledgments. We gratefully acknowledge the National Creative Research Initiative Program and the BK21 Program of Ministry of Education, Science and Technology for support of this work.

\section{References}

1. Lehninger, A. L.; Nelson, D. L.; Cox, M. M. Principles of Biochemistry; 2nd ed.; Worth Publishers: New York, NY, 1993; pp $240-267$. 
2. (a) Trembleau, L.; Rebek, J. Jr. Science 2003, 301, 1219-1220. (b) Scarso, A.; Trembleau, L.; Rebek, J. Tr. Angen. Chent. Int. Ed. 2003, 42, 5499-5502. (c) Scarso, A.; Trembleau, L.; Rebek, I. Jr. J. Am. Chem. Soc. 2004, I26, 13512-13518. (d) Schramm, M. P; Rebek, J. Jr. Chem. Eur. J. 2006, I2, 5924-5933. (e) Purse, B. W.; Rebek, J. Jr. Proc. Notl. Acad. Sci. USA 2006, 103, 2530-2534.

3. (a) Hohoff, C.; Spencer, F. FeffiLipid 1998, 100, 252-263. (b) Hanhoff, T.; Lucke, C.; Spener, F. Mol. Cell. Biochent. 2002, 239, 45-54. (c) Zannotti, G; Scapin, G.; Spadon, P.; Veerkamp, I. H.; Sacchettini, J. C. J. Biol. Chem. 1992, 267, 18541-18550. (d) Hohoff, C.; Borchers, T.; Rustow, B.; Spener, F.; van Tilbeurgh, H. Biochemistry 1999, 38, 12229-12239. (e) Balendiran, G K.; Schnutgen, F.; Scapin, G; Borchers, T; Xhong, N.; Lim, K.; Godbout, R.; Spener, F.; Sacchettini, T. C. J. Biol. Chem. 2000, $275,27045-27054$

4. Turo, N. J.; Okubo, T.; Chung, C.-J. J. Am. Chem. Soc. 1982 , 104, 1789-1794.

5. Ko, Y. H.; Kim, H.; Kim, Y.; Kim, K. Angew: Chem. Int. Ed. 2008 , $47,4106-4109$

6. (a) Mock, W. L. In Comprehensive Stpromolecular Chemistry; Vögtle, F., Ed.; Pergamon: Oxford, 1996; Vol. 2, pp 477-493. (b)
Lee, I. W.; Samal, S.; Selvapalam, N.; Kim, H.-T.; Kim, K. Acc. Chen. Res. 2003, 36, 621-630. (c) Kim, K. Chen. Soc. Rev: 2002, 31, 96-107. (d) Kim, K.; Kim, H.J. In Encrclopedia of Supramolecular Chemistri; Atwood, J. L.; Steed, J. W.. Eds.; Marcel Dekker: New York, 2004: pp 390-397. (e) Lagona, J.: Mukhopadhyay, P.; Chakrabarti, S.; lssacs, L. Angeat Chem. Int. Ed. 2005, 44, 4844-4870. (f) Kim, K.; Selvapalam, N.; Ko, Y. H.; Park, K. M.; Kin, D.; Kim, J. Chen. Soc. Rer: 2007, 36, 267279 .

7. (a) Kim, J.; Jung, l.-S.; Kim, S.-Y.; Lee, E.; Kang, J.-K.; Sakamoto, S.; Yamaguchi, K.; Kim, K. J. Am. Chem. Soc. 2000, 122, 540-541. (b) Day, A. I.; Anold, A. P.; Blanch, R. J.; Sinushall, B. J. Org. Chen 2001, 66, 8094-8100. (c) Liu, S.; Zavalij, P. Y.; Issacs, L.J. An. Chem. Soc. 2005, 127, 16798-16799.

8. Jeon, Y. J.; Bharadwaj, P. K.; Choi, S. W.; Lee, J. W.; Kim, K. Angen: Chem. Int Ed. 2002, 41, 4474-4476.

9. (a) Kim, H. J.; Heo, J.; Jeon, W. S.; Lee, E.; Kim, J.; Sakamoto, S. Yamaguchi, K.: Kim, K. Angen: Chem. Int. Ed. 2001, 40, 15261529. (b) Ko, Y. H.; Kim, E.; Hwang, I, Kim, K. Chem. Conmm. 2007, 1305-1315. (c) Lee, J. W.; Han, S. C.; Kim, J. H.; Ko, Y. H.; Kim, K. Bull. Korean Chen. Soc. 2007, 28, 1837-1840. 